\title{
ABSTRAK \\ TEAMS GAMES TOURNAMENT DALAM MENINGKATKAN \\ HASIL BELAJAR SISWA
}

\section{Hajrawati, Dosen Program Studi Pendidikan Biologi, STKIP-PI Pembangunan, Makassar 085343629112, E-mail: watihajra54@yahoo.com}

\begin{abstract}
Berdasarkan hasil analisis data yang diperoleh setelah melaksanakan penelitian dapat di simpulkan bahwa terdapat peningkatan hasil belajar dengan menggunakan model pembelajaran kooperatif tipe TGT (teams games tournament) pada materi sistem reproduksi manusia di SMA Batara Gowa. Berdasarkan hasil tes akhir Siklus I dan II, terdapat peningkatan hasil belajar peserta didik yaitu $21,74 \%$.
\end{abstract}

\section{kata kunci: tgt, hasil belajar}

\section{ABSTRACT \\ ITS TEAMS GAMES TOURNAMENT IN IMPROVING STUDENT LEARNING OUTCOMES}

Based on the analysis of data obtained after carry out research can be in conclude that there are increasing study result of the by using kind of classroom cooperative type TGT (teams games tournament) on matter the reproductive system of human in SMA Batara Gowa. Based on the test cycle the end I and II, there are increasing study result of the students are 21,74\%.

keyword: tgt, learning outcomes

Biologi merupakan salah satu juga dapat memberikan bekal bagi peserta cabang ilmu sains yang mendapat didik untuk dapat menerapkan biologi di perhatian dari pemerintah, mengingat hal berbagai bidang kehidupan, seperti tersebut kiranya dalam pendidikan genetika dan lain-lain.

biologi, guru perlu membekali peserta

Untuk itu guru diharapkan selektif didik dengan pengetahuan dan dalam menentukan dan menggunakan keterampilan yang bermanfaat demi model pembelajaran. Dalam proses belajar menjawab masa depan. Selain itu, biologi mengajar, guru harus menguasai prinsip- 
prinsip belajar mengajar, dalam hal ini adalah model pembelajaran yang tepat untuk suatu materi secara efektif dan efisie, maka tujuan yang diharapkan dapat tercapai. Sementara itu jika guru tidak mampu berperan dalam menyampaikan materi yang disajikan dalam model pembelajran, secara otomatis peserta didik juga pasif. Hal tersebut sering terjadi di sekolah, termasuk di SMA Batara Gowa. Faktor yang mempengaruhi rendahnya minat dan motivasi belajar siswa adalah adalah faktor lingkungan belajar yang kurang kondusif, metode pengajaran, kurangnya pengawasan orang tua, banyak guru yang mengajar menggunakan metode-metode yang sering digunakan, seperti metode ceramah dan metode buku. Banyak peserta didik yang kurang memahami materi-materi yang di sampaikan oleh guru, hal ini terbukti saat diadakan evaluasi pembelajaran.

Model pembelajaran kooperatif merupakan salah satu model pembelajaran kelompok yang dapat mengaktifkan peserta didik, baik fisik maupun mental, sebab dalam kelompok mereka diharapkan dapat bekerja sama dan berdiskusi untuk menyelesaikan permasalahan yang diberikan guru. Hal ini sesuai dengan
Slavin yang mengatakan bahwa, Cooperative learning (pembelajaran kooperatif) adalah suatu model pembelajaran, di mana peserta didik belajar dan bekerja dalam kelompokkelompok kecil secara kolaboratif, dengan struktur kelompoknya, yang bersifat heterogen (Silberman, 2010).

Dalam model pembelajaran kooperatif peserta didik dibutuhkan untuk saling membantu dalam memahami konsep berdiskusi dan menyelesaikan tugas-tugas yang berupa soal-soal latihan secara bersama. Dalam pembelajaran kooperatif dikenal adanya beberapa macam tipe, salah satunya adalah tipe Teams Games Tournament. TGT adalah suatu pendekatan yang melibatkan banyak peserta didik dalam menelaah materi yang tercakup dalam suatu pelajaran dan mengecek pemahaman mereka terhadap isi materi tertentu. Pada model Teams Games Tournament ini siswa dikelompokkan dalam tim pembelajaran yang merupakan campuran menurut tingkat kerja, jenis kelamin dan suku (Minarni, 2009).

Berdasarkan uraian di atas, maka penulis merasa tertarik untuk mengadakan penelitian dengan judul "Penggunaan 
Model Pembelajaran Kooperatif Tipe Teams Games Tournament (TGT) dalam Meningkatkan Hasil Belajar Biologi Materi Sistem Reproduksi Manusia Pada siswa Kelas XI Di SMA Batara Gowa"

\section{METODE PENELITIAN}

\section{Jenis Penelitian}

Penelitian ini merupakan penelitian tindakan kelas (Classroom Action Research) yang pelaksanaannya terdiri dari empat tahap yaitu: (1) perencanaan, (2) pelaksanaan tindakan, (3) pengamatan, (4) refleksi.

\section{Subjek Penelitian}

Subyek dalam penelitian ini adalah siswa kelas XI yang berjumlah 23 orang.

\section{Prosedur Penelitian}

Penelitian ini dilaksanakan dalam 2 siklus (siklus I dan siklus II), dimana pelaksanaan tindakan siklus I dengan siklus II merupakan rangkaian saling berkaitan. Pelaksanaan tindakan pada siklus II merupakan kelanjutan dari pelaksanaan tindakan pada siklus I. Secara sistematis keterkaitan antara setiap komponen dengan komponen lainnya dan antara siklus I dan siklus II dalam penelitian ini ditunjukkan dalam bentuk skema penelitian tindakan kelas:

\section{Siklus I}

1. Perencanaan

Adapun kegiatan yang dilakukan dalam tahap perencanaan ini adalah sebagai berikut:

a. Menelaah kurikulum (Standar Isi) kelas XI mata pelajaran Biologi yang berkaitan dengan materi sistem reproduksi manusia.

b. Membuat Rencana Pelaksanaan Pembelajaran (RPP).

c. Membuat lembar observasi aktivitas peserta didik untuk melihat bagaimana kondisi belajar mengajar di kelas ketika diberikan tindakan.

d. Evaluasi untuk mengukur hasil belajar biologi peserta didik dalam bentuk tes Multiple choise.

e. Membuat lembar jawaban untuk evaluasi siklus.

2. Pelaksanaan

Melaksanakan RPP yang telah dibuat. Kegiatan pembelajaran dilakukan dengan model pembelajaran kooperatif tipe Teams Games Tournament. Kegiatan belajar mengajar pada siklus I dilaksanakan selama 6 jam pelajaran yaitu tiga kali pertemuan, satu jam pelajaran berlangsung selama 45 menit. Secara 
umum tindakan yang akan dilaksanakan dalam tahap ini adalah.

a. Guru mengawali pelajaran dengan menjelaskan tujuan pembelajaran yang akan dicapai dan menggali pengetahuan awal peserta didik dengan mengajukan pertanyaan yang berhubungan dengan materi yang akan diajarkan.

b. Menjelaskan materi sistem reproduksi.

c. Guru membagi peserta didik dalam kelompok kecil beranggotakan 5-6 orang. Kemudian memberikan nomor anggota pada masingmasing kelompok.

d. Guru membagikan Lembar Kerja Siswa, pada setiap kelompok.

e. Peserta didik di minta untuk menyatukan pendapatnya dalam kelompok (Teams), untuk menjawab pertanyaan-pertanyaan tersebut.

f. Peserta didik di minta untuk memainkan permainan (Games), untuk menjawab soal-soal yang diberikan oleh guru. Apabila ada kelompok yang tidak mengerti dengan tugas yang di berikan, maka kelompok lain bertugas untuk menjawabnya.

g. Setiap kelompok bertanding (Tournament), untuk mendapatkan skor yang tinggi.

3. Pengamatan

Pada tahap pengamatan, yang dilakukan adalah observasi dan evaluasi.

a. Mengamati aktivitas peserta didik selama proses pembelajaran, menggunakan model pembelajaran kooperatif tipe Teams games tournament melalui lembar observasi.

b. Mengumpulkan data melalaui evaluasi hasil belajar pada siklus I.

c. Melakukan evaluasi terhadap data yang ada.

4. Analisis dan Refleksi

Hasil yang dicapai pada tahap observasi dan evaluasi dikumpul kemudian dilakukan analisis dan refleksi. Refleksi dimaksudkan untuk melihat kelemahan yang terjadi selama proses pembelajaran dengan menggunakan model pembelajaran kooperatif tipe Teams games tournament. Jika dalam siklus I masi ditemukan hal-hala berikut. Maka akan dilanjutkan ke siklus ke II. 


\section{Siklus II}

\section{Perencanaan}

Adapun kegiatan yang dilakukan dalam tahap perencanaan ini adalah sebagai berikut:

a. Menelaah kurikulum (standar isi) kelas XI IPA mata pelajaran biologi yang berkaitan dengan materi sistem reproduksi manusia.

b. Membuat Rencana Pelaksanaan Pembelajaran, dimana dalam RPP tersebut dimasukkan tindakantindakan untuk mengatasi kendala yang muncul pada siklus I agar pembelajaan dapat berlangsung baik. Adapun upaya yag dilakukan adalah sebagai berikut:

1) Memberikan pengarahan dengan penekanan pada kerjasama kelompok. Dengan tujuan, peserta didik dapat memahami manfaat dari kerjasama dalam kelompok. Peserta didik juga diajarkan untuk kerjasama dengan peserta didik lainnya dalam kelompok, yang berarti berusaha menerima kekurangan dan kelebihan masing-masing dan tidak menjadikannya sebagai halangan dalam kerjasama. Karena hasil pemikiran beberapa kepala akan lebih baik daripada hasil pemikiran satu kepala saja.

2) Memberikan penjelasan kembali mengenai model pembelajaran kooperatif tipe Teams Games Tournament. Penerapan pembelajaran ini antara lain bertujuan agar peran peserta didik dalam setiap kelompoknya dapat merata, dengan kata lain peserta didik mempunyai bagian yang sama dalam kelompok. Sehingga tidak ada yang merasa paling banyak perannya atau sebaliknya merasa tidak mempunyai peran sama sekali.

c. Membuat lembar observasi aktivitas peserta didik untuk melihat bagaimana kondisi belajar mengajar di kelas ketika diberikan tindakan.

d. Evaluasi untuk mengukur hasil belajar biologi peserta didik dalam bentuk tes multiple choice. 
e. Membuat lembar jawaban untuk evaluasi siklus.

2. Pelaksanaan

Melaksanakan Rancangan

Pelaksanaan Pembelajaran yang telah dibuat. Kegiatan pembelajaran dilakukan dengan model pembelajaran kooperatif tipe Teams Games Tournement. Kegiatan belajar mengajar pada siklus II dilaksanakan selama 4 jam pelajaran yaitu dua kali pertemuan, satu jam pelajaran berlangsung selama 45 menit. Secara umum tindakan yang akan dilaksanakan dalam tahap ini adalah.

a. Guru mengawali pelajaran dengan menjelaskan tujuan pembelajaran yang akan dicapai.

b. Memberikan pengarahan akan manfaat kerjasama kelompok, agar setiap anggota kelompok berusaha untuk menerima kekurangan dan kelebihan temannya, sehingga kerjasama yang baik akan tercapai. Misalnya, dengan memberikan perbandingan antara kelompok yang kerjasamanya baik dengan kelompok yang kerjasamanya kurang baik.

c. Menjelaskan kembali tujuan dari model pembelajaran kooperatif
TGT, salah satunya adalah agar peran setiap anggota kelompok sama, tidak ada lagi yang merasa paling berperan dalam kelompok ataupun merasa tidak berperan sama sekali.

d. Menjelaskan materi sistem reproduksi manusia, yang merupakan kelanjutan dari siklus I.

e. Guru membagi peserta didik dalam kelompok kecil beranggotakan 5-6 orang. Kemudian memberikan nomor anggota pada peserta didik masing-masing kelompok mulai dari nomor 1 sampai dengan 5.

f. Guru membagikan LKS (Lembar Kerja Siswa) pada setiap kelompok

g. Peserta didik di minta untuk belajar dalam kelompok (Teams) untuk menjawab soal-soal yang diberikan oleh guru.

h. Peserta didik diminta untuk memainkan permainan (Games), untuk menjawab soal-soal yang diberikan oleh guru. Apabila ada kelompok yang tidak mengerti dengan tugas yang di berikan, maka kelompok lain bertugas untuk menjawabnya. 
i. Setiap kelompok bertanding (Tournament) untuk mendapatkan skor yang tinggi.

j. Guru memberikan penghargaan (Rekognasi), kepada kelompok yang mempunyai skor tertinggi.

3. Pengamatan

Pada tahap pengamatan, yang dilakukan adalah observasi dan evaluasi, Kegiatan tersebut meliputi:

a. Mengamati aktivitas peserta didik selama proses pembelajaran menggunakan model pembelajaran kooperatif tipe Teams Games
Tournament (TGT) melalui lembar observasi.

b. Mengumpulkan data melalaui evaluasi hasil belajar pada siklus II.

c. Melakukan evaluasi terhadap data yang ada.

\section{Teknik Analisa Data.}

Data diperoleh dari hasil penelitian diolah dengan analisis statistik deskriptif. Untuk mengetahui berapa persen hasil belajar dan peningkatan atau tidak pada siklus 1 dan 2. dengan memakai Pedoman Acuan Patokan (PAP)

\section{HASIL PENELITIAN}

1. Hasil Tes Siklus I

Tabel. 1 Hasil tes akhir siklus I yang di sesuaikan dengan (PAP)

\begin{tabular}{|l|l|l|l|l|}
\hline Interval & Frekuensi & Presentase & Keterangan & Nilai Rata-rata \\
\hline $80-100$ & 10 & $43,47 \%$ & Baik sekali & \\
$66-79$ & 5 & $21,73 \%$ & Baik & \\
$56-65$ & 6 & $26,09 \%$ & Cukup & \\
$40-55$ & 2 & $8,69 \%$ & Kurang & \\
$0-39$ & 0 & $0 \%$ & Gagal & \\
\hline Jumlah & 23 & $100 \%$ & Jumlah & $78,26 \%$ \\
\hline
\end{tabular}

Tabel di atas menunjukan bahwa dalam tes siklus I. sehingga nilai rata-rata 10 orang peserta didik atau 43,47\% yang di capai oleh peserta didik sebesar memperoleh nilai baik sekali, 5 orang $(78,26 \%)$ dengan ketuntasan klasikal $75 \%$ peserta didik atau 21,73\% memperoleh karena dari 23 peserta didik yang nilai baik, 6 orang peserta didik atau mencapai Kriteria Ketuntasan Minimal 26,09\% memperoleh nilai cukup, dan 2 (KKM) sebesar 65 baru 18 orang peserta oarng peserta didik atau $8,69 \%$ didik. Maka hasil tes di atas menunjukan memperoleh nilai kurang, serta tidak ada bahwa 2 orang peserta didik lainnya peserta didik yang di nyatakan gagal belum mencapai Kriteria Ketuntasan 
Minimal (KKM). Sehingga peneliti memperbaiki kekurangan pada siklus II.

2. Hasil Tes Siklus II

Tabel. 2 Hasil tes akhir siklus II yang di sesuaikan dengan (PAP)

\begin{tabular}{|l|l|l|l|l|}
\hline Interval & Frekuensi & Presentasi & Keterangan & Nilai rata-rata \\
\hline $80-100$ & 14 & $60,87 \%$ & Baik sekali & \\
$66-79$ & 6 & $26,09 \%$ & Baik & \\
$56-65$ & 3 & $13,04 \%$ & Cukup & \\
$40-55$ & 0 & $0 \%$ & Kurang & \\
$0-39$ & 0 & $0 \%$ & Gagal & \\
\hline Jumlah & 23 & $100 \%$ & Jumlah & 100 \\
\hline
\end{tabular}

Tabel di atas menunjukan 14 orang

peserta didik atau $60,87 \%$ memperoleh

Berdasarkan hasil tes siklus I nilai baik sekali, 6 orang peserta didik menunjukan bahwa 10 orang peserta didik atau 26,09\% memperoleh nilai baik, 3 atau 43,47\% memperoleh nilai baik sekali, orang peserta didik atau 13,04\% 5 orang peserta didik 21,73\% memperoleh memperoleh nilai cukup. Dan tidak ada nilai baik, 6 orang atau 26,09\% peserta didik yang dinyatakan gagal dalam memperoleh nilai cukup dan 2 orang mengikuti pembelajaran dengan peserta didik atau $8,69 \%$ memperoleh menggunakan model pembelajaran nilai kurang dan tidak ada peserta didik kooperatif tipe TGT pada materi sistem yang dinyatakan gagal. Hal ini reproduksi manusia. Dari hasil rata-rata menunjukan bahwa sebagian peserta didik yang di capai peserta didik sebesar $100 \%$ belum mencapai Kriteria Ketuntasan dapat dilihat bahwa seluruh peserta didik Minimal (KKM). Bertolak dari refleksi atau 23 peserta didik mencapai Kriteria siklus I, maka pada pelaksanaan tindakan Ketuntasan Minimal (KKM) yang sudah pada siklus II peneliti lebih memperbaiki di tentukan. Dengan ketuntasan klasikal cara penyampaian materi-materi yang 100\%. Hal ini menunjukan bahwa seluruh belum di pahami oleh peserta didik peserta didik telah mencapai Kriteria Ketuntasan Minimal (KKM). Olehnya itu peneliti tidak melanjutkan ke siklus berikutnya.

kemudian peneliti melakukan tes akhir siklus II.

Berdasarkan tes akhir siklus II menunjukan 14 orang peserta didik atau $60,87 \%$ memperoleh nilai baik sekali, 6 
orang peserta didik atau 26,09\% memperoleh nilai baik, 3 orang peserta didik atau $13,04 \%$ memperoleh nilai cukup dan tidak ada peserta didik yang di nyatakan gagal. Dengan demikian dapat dilihat bahwa ada peningkatan hasil belajar peserta didik dari tes akhir siklus I dan II yaitu 21, 74\%.

Sedangkan kelebihan dari TGT adalah meningkatkan harga diri sosial pada peserta didik, meningkatkan perasaan atau presepsi bahwa hasil yang mereka peroleh tergantung dari kinerja dan keterlibatan peserta didik lebih tinggi dalam belajar bersama (Djamarah, 2006).

Dari hasil penjelasan di atas secara umum dapat di katakan bahwa pembelejaran dengan model pembelajaran kooperatif tipe TGT dapat meningkatkan hasil belajar peserta didik di pandang sisi presentase siklus demi siklus yang terdapat dalam hasil belajar peserta didik dengan model pembelajaran kooperatif tipe TGT pada materi sistem reproduksi manusia di SMA Batara Gowa.

\section{KESIMPULAN}

1. Berdasarkan hasil analisis data yang diperoleh setelah melaksanakan penelitian dapat di simpulkan bahwa terdapat peningkatan hasil belajar dengan menggunakan model pembelajaran kooperatif tipe TGT (teams games tournament) pada materi sistem reproduksi manusia di SMA Batara Gowa.

2. Berdasarkan hasil tes akhir Siklus I dan II, terdapat peningkatan hasil belajar peserta didik yaitu $21,74 \%$.

\section{SARAN}

1. Mengingat model pembelajaran kooperatif tipe TGT dapat meningkatkan hasil belajar peserta didik pada materi sistem reproduksi manusia, maka perlu di coba dengan menggunakan model pembelajaran serupa yang dapat meningkatkan hasil belajar peserta didik.

2. Mengingat dalam penelitian baru berjalan dalam 2 siklus, maka guru lain yang ingin menggunakan penelitian yang sama agar di lanjutkan guna mendapatkan hasil belajar yang lebih baik.

3. Penulis sangat mengharapkan masukan yang bersifat membangun demi penyempurnaan karya ilmiah ini dan dapat di gunakan sebagai referensi 
dan hasil penelitian ini bisa di lanjutkan oleh peneliti yang lain.

\section{DAFTRA PUSTAKA}

Budiningsi H. Asri. 2005. Belajar dan Pembelajaran. PT Rineka Cipta. Jakarta.

Departemen Pendidikan dan Kebudayaan RI. 1991. Kamus Besar Bahasa Indonesia Edisi Kedua. Balai Pustaka. Jakarta.

Djamara, Syaiful Bahri. 2006. Strategi Belajar Mengajar. PT Rineka Cipta. Jakarta.

Minarni. 2009. Upaya Peningkatan Hasil Belajar PKn Model Pembelajaran Problem Based Learning siswa kelas X MAN I Model kota Bengkulu. MAN I Model Bengkulu. Bengkulu.

Mulyasa, E. 2008. Menjadi Guru Profesional. PT Remaja Rosada Karya. Bandung.

Munthe, Bermawi. 2009. Desain Pembelajaran. PT Pustaka Insan Madani. Jogjakarta.

Pupuh dan M. Sobry, 2009. Strategi Belajar Mengajar. PT Rafika Aditama. Bandung.

Pribadi, Benny A. 2009. Model Desain Sistem Pembelajaran. Dian Rakyat. Jakarta.

Silberman dalam Silkia Puspita Kencana. 2010. Strategi Pembelajaran Inquiring Minds Want To Know (Menggali Pikiran Yang Ingin Tahu) Dan True Or False (Benar Atau Salah) Untuk Meningkatkan Hasil Belajar Biologi Pada Pokok Bahasan Keanekaragaman Hayati Pada Siswa Kelas X1 Man 1 Surakarta. Skripsi. Universitas
Muhammadiyah Surakarta. Surakarta.

Sudjana, Nana. 1996. Kurikulum di Sekolah. Sinar Baru Algesindo. Bandung.

Suryosubroto, D. 1990. Dasar-dasar Kependidikan. Rineka Cipta. Jakarta.

Usman, Uzer. 2005. Menjadi Guru Profesional. Remaja Rosdakarya. Bandung 